\title{
Space of Mediation: Labour Migration, Intermediaries and the State in Indonesia and China since the Nineteenth Century
}

L'espace de la médiation: intermédiaires et État en Indonésie et en Chine depuis le XIXe siècle

Espacio de mediación: migración laboral, intermediarios y el Estado en Indonesia y China desde el siglo XIX

Johan Lindquist and Biao Xiang

\section{OpenEdition}

Electronic version

URL: https://journals.openedition.org/remi/12529

DOI: 10.4000/remi.12529

ISSN: $1777-5418$

Publisher

Université de Poitiers

Printed version

Date of publication: 1 October 2019

Number of pages: 39-62

ISBN: 979-10-90426-64-1

ISSN: 0765-0752

Electronic reference

Johan Lindquist and Biao Xiang, "Space of Mediation: Labour Migration, Intermediaries and the State in Indonesia and China since the Nineteenth Century", Revue européenne des migrations internationales [Online], vol. $35-n^{\circ} 1$ et 2 | 2019, Online since 01 January 2021, connection on 16 April 2022. URL: http://journals.openedition.org/remi/12529 ; DOI: https://doi.org/10.4000/remi.12529 


\title{
Space of Mediation: Labour Migration, Intermediaries and the State in Indonesia and China since the Nineteenth Century
}

\author{
Johan Lindquist ${ }^{1}$ and Biao Xiang ${ }^{2}$
}

It has been increasingly recognized among scholars that migration is mediated by different actors, including those who appear far removed from migrants (Feldman, 2012). Existing literature has pointed out that focusing on processes of mediation provides us with a critical lens to appreciate the relation between migration and broader social change (Mezzadra and Neilson, 2013; Sørensen and Gammeltoft-Hansen, 2013; Walters, 2015). Arguably this is particularly evident in Asia where brokers have historically had a crucial role in labour migration (Lindquist, Xiang and Yeoh, 2012). In light of this, the article asks how specific modes of migration mediation have changed over time in Asia, especially in relation to the state. This question will be addressed by examining the case of low-skilled international labour outmigration from China and Indonesia since the nineteenth century.

Our comparison is grounded in what we term "spaces of mediation." Space of mediation is a conceptual construction, and not a self-evident empirical object. We use "space" in order to capture the complex connections among multiple actors, which are neither clearly localized nor bounded, but centered on the mediation of migration. This space forms an emergent arena of practices and is defined by a constantly changing configuration of multiple connections. The central actors of this space are neither migrants nor state regulators, but are nevertheless indispensable to both the process of and the governance of migration. These actors address the demands of migrants and regulators, but always in the light of their own interests. In the contemporary era, they include commercial recruitment intermediaries - big and small, formal and informal as well as quasi-government public institutions (such as business associations), NGOs and public media. The multidirectional connections among these actors and the entanglement between their divergent concerns create quasi-autonomous dynamics that actively shape the mediation process. A historical perspec-

1 Professor, Stockholm University, Department of Social Anthropology, Stockholm University, SE-106 91, Stockholm, Sweden; johan.lindquist@ socant.su.se

2 Professor of Social Anthropology, Institute of Social and Cultural Anthropology, University of Oxford, 51/53 Banbury Road, Oxford, OX2 6PE; biao.xiang@ anthro.ox.ac.uk 
tive suggests not only the enduring centrality of the space of mediation in terms of organizing labour circulation, but also ongoing shifts in the balance of power in relation to the state. Taking the "space" of mediation as an entry-point, we investigate how states play their roles in practice without assuming the existence of an autonomous and bounded "state" separated from "society" or "market."

This article compares the space of migration mediation in China and Indonesia (the Dutch East Indies before 1945) at three modern stages: 1) the period before the entrenchment of the centralized state; 2) the era of national development under the centralized state; and 3) the period since the late 1990s that has been characterized by increasing deregulation in some aspects and re-regulation in others (cf. Table 1). Our comparison shows that, despite the obvious differences between the two states, the space of mediation has followed a comparable evolution. Before China and Indonesia became effectively centralized, the space of mediation was socially autonomous, occupied by identifiable social groups that often served as a link between otherwise separated worlds. In the era of national development, the centralized states aimed to control the space of mediation directly, in terms of both business ownership and operational methods. In the late 1990s the space of mediation in both Indonesia and China underwent a double transformation. First, intermediaries increasingly regained economic autonomy in the wake of market liberalization. In China, public institutions were explicitly banned from commercial labour brokerage, which brought in various kinds of private players and the space expanded rapidly in scope. In Indonesia, economic liberalization and the dismantling of Suharto's monopolies led to a dramatic growth of labour recruitment companies. Second, however, independent business ownership has not brought about the form of social autonomy that pre-1960s intermediaries enjoyed. States control intermediaries through licensing and de-licensing, monitoring of business conduct, and guidelines about how different types of intermediaries should work together. Both states are hands-off in spirit, hands-on in operation. The following Table summarizes the historical changes.

Table 1: Historical Changes in the Space of Mediation of Labour Migration

\begin{tabular}{lccc}
\hline Period & Political context & Key players & Features \\
\hline $\begin{array}{l}\text { Mid-19 } \\
20^{\text {th }} \text { century }\end{array}$ & $\begin{array}{c}\text { Pre-centralized nation- } \\
\text { states (colonialized or } \\
\text { semi-colonialized) }\end{array}$ & $\begin{array}{c}\text { Local elites, } \\
\text { representative of } \\
\text { foreign/colonial } \\
\text { enterprises, civil } \\
\text { associations }\end{array}$ & $\begin{array}{c}\text { Semi-autonomous, and } \\
\text { poorly regulated }\end{array}$ \\
\hline $\begin{array}{l}\text { Second half of the } \\
20^{\text {th }} \text { century }\end{array}$ & $\begin{array}{c}\text { Centralized, } \\
\text { developmental states }\end{array}$ & $\begin{array}{c}\text { Bureaucrats; informal } \\
\text { (illegal) brokers }\end{array}$ & $\begin{array}{c}\text { Bifurcated (state } \\
\text { controlled versus } \\
\text { outlawed) }\end{array}$ \\
\hline $\begin{array}{l}\text { The end of the } \\
20^{\text {th }} \text { century onwards }\end{array}$ & Globalizing states & $\begin{array}{c}\text { Licensed recruitment } \\
\text { companies and } \\
\text { associated agents }\end{array}$ & $\begin{array}{c}\text { Integrated, } \\
\text { professionalized, } \\
\text { regulated }\end{array}$ \\
\hline
\end{tabular}

This comparison is part of our on-going conversation based on long-term field research on labour migration from Indonesia and China over the last two decades. Most recently Lindquist has worked on outmigration from Indonesia, particularly the island of Lombok (ten months between 2007 and 2017), and Xiang on northeast China, particularly Liaoning province (a total of twelve months between 2004 and 2008, and in 2011 and 2017). Lombok is a major sending area 
for male oil palm plantation workers to Malaysia and women migrants to Asia and the Middle East, which was partially driven by the economic hardships resulting from the 1997 Asian financial crisis. ${ }^{3}$ Liaoning Province emerged as a new emigration place in the 1990s amidst massive labour layoffs resulting from the privatization of state-owned enterprises that escalated in 1998. We both realized that, in order to deepen our understanding of the present, we needed to trace it back historically. This article represents fieldwork-informed, historically-based, and comparatively-framed research. It is fieldwork-informed in the sense that our central theoretical question, namely the relation between intermediaries and the state, was derived from our field research on the contemporary condition. We have collected historical data from documentary research. Our analysis of the changes after the mid-twentieth century is based on a mix of information sources, which include scholarly publications, government documents, interviews and field observations. The article is comparatively-framed not only in the sense that it discerns differences and similarities between Indonesia and China, but more importantly, maps continuities and discontinuities across historical stages through comparisons between the two countries. Instead of confining our analysis to labour migration intermediaries alone, we investigate changes in the general intermediary classes between the state and the local society, of which migration intermediaries have been a part.

\section{The "Link Society" Model of the Late Nineteenth and Early Twentieth Centuries}

Large-scale labour migration to and from Asia was initiated in the first half of the nineteenth century as the demand for natural resources across the region exploded in the wake of capitalist expansion, made possible by colonial intervention and transportation innovations such as the steamship. In this process, Asia experienced a "mobility revolution" (Amrith, 2011: 25-29). An estimated average of 150,000 Chinese emigrated annually, leading the Chinese population in Southeast Asia to increase ten-fold between 1840 and 1949 (Cao, 1997: 531). ${ }^{4}$ Chinese migrants were initially the main source of labour in plantations and mines in the outer islands of the Dutch East Indies, but near the end of the nineteenth century the Dutch colonial state increasingly turned to the growing Javanese population to replace them (Houben, 2018). In this process, Javanese migrants became indentured labourers in plantation belts and mining enclaves in the outer islands of the Dutch East Indies and further afield in Surinam, Malaya, and New Caledonia (Hoefte and Meel, 2018).

An important part of the mobility revolution was the emergence of a space of mediation that linked previously separate societies, either between the colonial and the native, or between formal systems and informal social life, which together with new forms of transport made the actual recruitment and

3 In 2011 East and Central Lombok were the Indonesian regencies with the second and fourth largest number of migrants departing during that year, respectively. Data from the National Agency for the Protection and Placement of International Migrant Workers (BNP2TKI).

4 In the 1850s there were about 1 million Chinese in Southeast Asia (Zhuang, 1994: 55), and the population increased to more than 7 million in the 1920 s and to 10 million in the 1940s (Guo, 1989: 118). 
movement of labour across great distances possible. In the Dutch East Indies, indirect colonial rule was institutionalized as a system of intermediaries between populations and societal spheres. The idea of the schakel or "link" society suggested that cultural links could serve as a "channel" connecting "strange worlds" (Abdullah, 1978: 148, cited in Kuitenbouwer, 1980: 105). While ethnic Chinese functioned as middlemen in the colonial economy (Rush, 1990), the Javanese priyayi aristocracy had a similar role in the political and bureaucratic spheres (Sutherland, 1979), and local strongmen, jago, exchanged "order" for the right to engage in extortion, theft, and banditry (Wilson, 2015: 11-13). ${ }^{5}$ Labour migration came to be conceived and organised in similar terms thus forming the basis for the space of mediation. In China, a new space of mediation emerged because the traditional intermediary structure centered on gentries collapsed, and new linkages had to be made between local societies and foreign powers that demanded labour. In the space of mediation in both countries, private labour brokers and (quasi)colonial officers played important roles by creating infrastructure such as temporary housing and labour depots, as well as funding migration itself (Kaur, 2004: 51).

In the Dutch East Indies, the recruitment of Chinese migrants was initially handled by Chinese brokers via the British Straits Settlements, but as fees increased Dutch private companies received permission to recruit in China beginning in 1888 (Termorshuizen, 2008: 272-273). Even with direct recruitment Chinese labour remained expensive and was increasingly replaced by Javanese migrants recruited by Dutch firms (Houben, 1999a: 3). With a series of Coolie Ordinances aimed to protect the interests of plantation companies by outlining sanctions against workers who violated contracts (Breman, 1990: 63; Tirtosudarmo, 2001: 203), the Dutch attempted to create the basis for an administrative and legal system that would guarantee the circulation of indentured labour to the plantation belts in outer islands (Houben, 1999a: 3). The number of migrants deployed to the outer islands, East Sumatra in particular, was far greater than those sent abroad to other Dutch colonies, such as Surinam, and English and French colonies such as Malaya and New Caledonia, as the colonial authorities in the East Indies aimed to monopolize the substantial Javanese labour reserve (Houben, 2018: 62-63).

The coercive and criticized Cultivation System (1830-1870), based on Javanese corvée labour, gave way to the Ethical Policy (1901), which purported to improve the welfare of colonial subjects. In this process, there was a rapid increase in the number of specialized government departments (Cribb, 1993: 233; see also Sutherland, 1979: 14), and, more generally, a "huge extension of the state apparatus deep into native society and a proliferation of its functions" (Anderson, 1983: 479). This was evident not least in the context of migration, as Javanese migration was perceived both as a way of supplying labour and reducing overpopulation. The so-called "colonization" (kolonisasi) program was initiated in 1905, which permanently moved Javanese peasants to the outer islands (Hardjono, 1988: 427; see also Stoler, 1985: 38), while Recruitment Ordinances (in 1909 and 1914) ostensibly aimed to prevent abuses against

5 In this role, the priyayi became the agents of intensifying state intervention in vaccination campaigns, taxation, and corvée labor, thus increasingly becoming associated with the colonial state (Sutherland, 1979: 16). 
coolies, as an extensive series of regulations were made compulsory for recruitment firms. Firms and their recruiters had to be licensed and have well-maintained labour depots in their areas of recruitment, while a limited number of recruitment commissionaires (wervingscommissarissen) were in charge of surveilling the implementation of these regulations (Houben, 1999b: 32-34). Notably, the regulations and broader recruitment system for migrants sent to Surinam and other destinations abroad were governed by the same regulations as those within the East Indies (Houben, 2018: 62-63).

Labour recruitment on Java was divided between a handful of Dutch firms, each with three types of personnel: the mainly European recruiters, the Javanese henchmen (handlangers or glundungan) and the Javanese overseers (mandor), of whom the latter two would approach prospective migrants. State labour inspectors generally blamed henchmen and overseers for engaging in deception and extortion and luring villagers to become coolies under false pretenses (Houben, 1999b: 30). Plantation corporations in the outer islands, with the support of colonial officials who complained that costs were too high while anticipating that the commercial recruitment agencies would not be able to deliver enough workers, created their own recruitment systems (Stoler, 1985: 28; Houben, 1999b: 34). The so-called personal recruitment system was based on sending workers back to Java to recruit family members and fellow villagers. These laukeh (Hokkien for "veteran") were to be monitored by European representatives of the companies along the way and were likely modeled on earlier forms of direct recruitment in China. Although apparently different, in practice the "two systems were virtually identical" since they made use of the same village-level recruiters (Houben, 1999b: 36), thus illustrating how attempts to establish new forms of labour recruitment were inevitably embedded in already existing networks and relationships (Ibid.: 27).

The predominance of firms and extensive use of village-level recruiters highlight the multiple levels of mediation between the state and prospective migrants that characterized the "link society", and which created the basis for a space of mediation for labour migration. This space was shaped as the "village" itself became a site of colonial concern (Breman, 1988). During the Cultivation System, the Javanese peasant economy had become organized on a territorial basis by the colonial state, as the village became the primary unit for the extraction of labour and taxes (Breman, 1988: 16). The creation of travel passes further regulated labour mobility and positioned the village chief in a mediating position of power (Barker, 1999: 127-128), not least when it came to the recruitment of migrant labour (Termorshuizen, 2008: 267). During the colonization program, migrants were often chosen by village chiefs who could take the opportunity to displace unwanted residents (Ibid:: 2008: 294). Although it was critical for priyayi to retain good relations with village heads because of the colonial demands for rust en orde (peace and order) they increasingly belonged to different social worlds. As Stoler (1985: 25) has put it, "peasants remained village residents whose contact with the colonial apparatus was cushioned and muted by a layer of native civil servants." It was thus the social rather than economic autonomy of the village that made brokers both necessary and a problem for labour recruitment companies and colonial authorities. 
As noted, China's involvement in the mobility revolution was very different. The dramatic increase of outmigration after 1860 was directly related to the encroachment of Chinese sovereignty and the displacement of one space of mediation composed by traditional locally rooted gentries by another consisting of commercial players and local thugs backed by foreign powers. In imperial China, gentry in the countryside functioned as a link between a centralized but small bureaucracy, on the one hand, and the massive rural society, on the other (Wu and Fei, 1948). They assisted the imperial state with ensuring social order (including preventing large-scale outmigration either to other parts of China or overseas) (see Kuhn, 2008), maintaining public programs such as education and irrigation, and collecting taxes. In turn they represented the local society in negotiating with the state, particularly regarding tax deduction and relief provision in years of hardship.

This space of mediation was undermined with the decline of central power and recurring social upheavals. The gentry scholars's intermediary role was overtaken by entrepreneurial, and often predatory individuals who had connections with the fragile modern state and foreign powers (Duara, 1987). After humiliating defeats in two Opium Wars (1839-1842, and 1856), the Qing court was forced to sign the Beijing Treaty in 1860, which conferred foreign companies the freedom to recruit workers in China to feed the expanding colonial economy worldwide, but primarily in Southeast Asia. Major colonial powers set up recruitment bureaus in key cities and dispatched officers to different parts of China, who in turn relied on local brokers to recruit workers. Called ketou (head of guests) or zhuzaitou (head of piggy), the local brokers often deceived or even kidnapped young men to port cities, particularly Hong Kong, where they were trafficked overseas. Colonial ports became the focal points of this early form of human smuggling, and triad gangs played an important role in recruitment (Ong, 1995). Recognizing the widespread problems, the Qing government banned outmigration recruitment in 1891, and in 1905 the governor of Guangdong, one of the major migrants sending areas, ordered all recruitment agencies to be closed down. But with the support of foreign consular offices, both foreign and local recruiters continued with the business (e.g. Mao, 2004, see also Cao, 1997). Traditional gentries and other local leaders were helpless, though some did launch campaigns attempting to stop the recruitment, including standing in the ports to dissuade men from boarding recruiters' boats. The mediation process that linked foreign powers and Chinese local societies remained unregulated after free passage workers replaced indentured workers as the main channel of outmigration in 1893. An estimated 7 million Chinese were brought overseas by these intermediaries (Chen Hansheng cited in Li, 2002: 99).

Between 1915 and 1918 Russia, France and Britain recruited an estimated 300,000 Chinese workers to support their First World War efforts, for instance as transport workers and trench builders (see Zhang, 2009; Xu, 2011; O'Neill, 2014; Bailey, 2014; Ma, 2015; Wood and Arnander, 2016). The workers were recruited by Chinese companies with foreign connections, or sometimes by foreign agents directly, and were tacitly endorsed, but hardly regulated, by the Chinese government. Most were not properly informed about the war conditions ( $\mathrm{Li}$, 2002: 99-113). Appalled by the unethical recruitment procedure and the abuse that the workers faced overseas, particularly in France, a group of revolutionaries belonging to the Association for Work-Study in France (established in 1912) 
experimented with alternative recruitment methods in 1916. They successfully negotiated with the French government and employers to ensure equal pay for Chinese workers to study French at work, direct payment of travel costs and wages to workers rather than through recruiters. The Association then worked with education officers and primary school teachers in hinterland China to recruit literate workers without criminal records, although the number was small ( $\mathrm{Li}$, 2002: 106-107; Dirlik, 1991: 326). It is important to note that active participants in the Work-Study in France Movement included Mao Zedong (who actively promoted the movement and recruited a number of worker-students in his home province Hunan, though he did not go to France himself), Zhou Enlai, Zhu De, Deng Xiaoping and other prominent Communist leaders. As such, the space of mediation was not only socially autonomous, but also became politically revolutionary.

Regardless of the nature of these intermediaries, be they traditional aristocrats or modern entrepreneurs, their social autonomy caused grave concerns for modernizing state. This was true in the Dutch East Indies as well, where even before independence in 1945, the colonial state, while heavily reliant on intermediaries, was also keen to curtail them. While the Recruitment Ordinances aimed to regulate labour recruitment through documentation, officials hoped that dactyloscopy, the science of fingerprint identification, would form the basis for a modern labour system in the Indies through the registration and, as Dutch experts put it, the "sieving" of contract workers (Mrazék, 2002: 101-102). While there was a predictable lack of implementation in the context of labour migration, the proposed use of dactyloscopy was an example of the "fetishization of the tools of surveillance" that characterized the Dutch regime (Barker, 1999: 166). In the divided Dutch colonial society and administration these technologies were imagined as bridging a gap that was inhabited by brokers (see, for instance, Kuitenbrouwer, 1980; Barker and Van Klinken, 2009: 22) who controlled access to prospective migrants independently of any broader recruitment system that was created by state or market actors.

In China, intermediaries were of such a great concern that they stood out as a rare common enemy of diverse social groups. Conservative mandarins, radical reformists and socialist revolutionists all "placed the problem of controlling or eliminating middlemen near the top of China's constitutional agenda" (Kuhn, 2002: 91). The fact that the Republic of China, which was established in 1912, repeatedly failed to control such intermediaries as those who recruited workers for Europe during the First World War is widely seen as a result of its failure in unifying China, centralizing power and protecting sovereignty, a fundamental weakness that for many had to be overcome through radical social changes.

As McKeown has pointed out more broadly, with the rise of liberalism and "free" labour (as opposed to indentured or debt-bondage labour), informal recruiters were increasingly demonized and connected to premodern forms of labour organization, despite the fact that most were a product of the capitalist economies and mass migrations associated with modernity (McKeown, 2008: 116). In contrast to social relationships, an emerging form of proceduralism based on documentation or technologies such as fingerprinting increasingly came to be seen as a mode of regulating mobility (Ibid.: chapter 10). As is clear from both cases, however, the space of mediation that came to be inhabited by 
various kinds of brokers was difficult to regulate, not least because the state lacked the basic capacity to penetrate local societies that were separated from the modern bureaucracy.

\section{Space of Mediation as a State Project for National Development}

The link society model was fundamentally dismantled by the centralized states in both Indonesia and China, and new types of mediation were put in place. The early post-colonial Indonesian state was burdened by debt from the war and distinguished by the penetration of the state by societal groups that gained influence during the revolution and independence from the Netherlands, between 1945 and 1949. In this process, the state bureaucracy grew ten-fold between 1940 and 1968 to 2.5 million civil servants (Anderson, 1983: 482-483). However, the rise of Suharto's New Order regime, following the destruction of the communist party beginning in 1965, led to the reestablishment of the power of the state vis-à-vis society, as the Indonesian state, by way of the military, was able to nationalize foreign corporations. Power was thus increasingly consolidated and centred on the Suharto family and their crony capitalist network. Furthermore, the Indonesian family planning and transmigration programs are intimately connected with the power of the New Order state to reach into the intimate spheres of everyday life (Warwick, 1986). The latter was based on the Dutch colonization program, renamed transmigrasi when it was initiated in 1950, as the Indonesian state revived the process of moving peasants from overpopulated Java, in particular, to less densely populated areas in the outer islands (Tirtosudarmo, 2009). The two programs shared comparable ambitions with regard to demographic engineering and nation-building, as well as transforming livelihoods, and were supported by international organizations such as the World Bank (Tirtosudarmo, 2001).

What is particularly noteworthy, primarily in light of this article, was the use of the petugas lapangan, or "field agent", who recruited "acceptors" (akseptor) in family planning programs in the early 1970s and supported new arrivals in the transmigration program. In the context of family planning, the petugas lapangan was eventually given the status of civil servant (Niehof and Lubis, 2003: 126-127), thus signaling the state's attempt to directly access the village and thereby control the space of mediation. The term itself connotes a connection to a bureaucracy and thereby an extension of the state apparatus, rather than a broker whose allegiances are divided, thus pointing beyond the "link society" that characterized the colonial era towards a more expansive form of engagement that has been termed "bureaucratic authoritarianism" (King, 1982). After the 1997 economic crisis, the petugas lapangan became increasingly critical in the recruitment process, as well as a site of state regulation, with the rise of international migration, a point we will return to later.

A national overseas labour migration program was first conceptualized by the Indonesian government in the late 1960s, partly in response to transmigration's limited effects on the rising problem of unemployment. From the beginning, a key task of the Ministry of Manpower was to gain control over already existing flows of international migration, by creating a space of mediation through 
the licensing of private recruitment companies. It took more than a decade, however, before international labour migration became an explicit dimension of national development. In the wake of the global recession in the early 1980s, and particularly after the global slump in oil prices in 1986, which seriously affected the Indonesian economy, state bureaucrats and policymakers saw international labour migration, primarily female domestic workers to Saudi Arabia, as a possible solution to both Indonesia's foreign exchange and labour market problems (Cremer, 1988; Palmer, 2016: Chapter 2). In order to more efficiently regulate increasing flows of migrants, and to convince migrants to choose documented over undocumented migration, the Centre of Overseas Employment (Pusat AKAN) was created within the Department of Manpower in $1984 .{ }^{6}$

Migration and trade were considered explicitly together, thus placing international migration in the context of broader economic policy (Palmer, 2016: 26-28). In fact, there was a general agreement that the welfare and rights of Indonesian workers should not take precedent over national development. In line with this, and in order to make Indonesian workers more competitive - as the country was a latecomer to labour export compared to the Philippines - the costs of recruitment were shifted from employers to workers (Ibid.: 37). Throughout the 1980s and 1990s the government regulated licenses for recruitment companies, while starting a state-owned company, PT Bijak, in order to influence and regulate the market by creating competition and protecting migrants. During this period, there was also an expansion of particularly male irregular migration to Malaysia. To a certain degree this was a continuation of historical patterns, but also an effect of the growth of the Malaysian economy and, in particular, the oil palm economy. Much of this migration became increasingly clandestine with the growing demands for migration documentation in Indonesia and the gradual expansion of the Malaysian deportation regime. Within this space of mediation, the tai kong ("ship's captain" in Chinese), the migrant smuggler, and the calo, the murky low-level middleman pervasive in Indonesian everyday life, became a critical figure in the movement of Indonesian migrants across the border (Spaan, 1994; Jones, 2000).

The policy transformations of the 1980s and 1990s thus led to the increasing bifurcation of state-controlled female migration and illegally brokered male migration. Most licensed recruitment companies were based in Jakarta and other major cities, while provincial branch offices recruited villagers, primarily Javanese women. With regard to undocumented migration, chains of tai kong connected rural villages, border areas, and employers abroad, thereby bypassing urban centres. The divisions between the two migration channels were not clearcut, however, as both were characterized by unclear boundaries between state and non-state actors and depended on village recruiters. As during the colonial period, evidence suggests that village heads and return migrants remained important in the recruitment process (Spaan, 1994), while state officials at the border were engaged in making money off migrants (Jones, 2000).

6 The creation of the centre was influenced by a similar migration-specific government agency in the Philippines (Spaan, 1999: 158-159; Palmer, 2016: 31-32). More generally, the improvement of state capacities to regulate migration was supported by the ILO and UNDP, and was part of a global trend in the 1980s to make international migration to Europe and the United States more legible (Palmer, 2016: 40-41). 
In China, spontaneous labour outmigration was almost completely stopped after the Communist Party took over in 1949. State foreign aid projects that sent (mainly skilled) personnel to more than 50 developing countries in Latin America, Africa, Asia and East Europe (He Xiankai, 1994: 150-162) was the main channel of international labour deployment, managed by the Foreign Economic Liaison Ministry (later the Ministry of Commerce) with branches in all provinces ("bureaus") and cities ("offices"). When the central government decided to start a project overseas, the ministry would require the bureau in a particular province with suitable expertise and labour force to implement the project. The provincial bureau might in turn ask municipal offices to do the same. As such, there was no space of mediation as labour deployment was directly administered by state regulators. In the reform era following the Cultural Revolution a new space of mediation emerged. This space was initially led by four stateowned companies set up by the central government in 1982, called "central companies", which carried out international projects on a commercial basis. All the central companies started their international business as labour suppliers, but soon realized that established players in the industry hardly engaged in labour-intensive tasks and instead specialized in design and management. The central companies thus increasingly subcontracted labour-intensive tasks to other companies in China from the mid-1980s. The subcontractor carried out the project independently, and the central company profited from the gap between the amount paid by foreign clients and that paid to the subcontractor. Even when the subcontractor secured a deal with foreign clients, the project had to be presented as that of the central company because the latter were the only legitimate "windows" through which Chinese companies could access the international market. The subcontractor thus had to pay the central companies a "window fee."

The space of mediation enlarged in the late 1980s with the establishment of provincial "windows," which were formerly Provincial Bureaus of Foreign Economic Liaison reorganized into companies. The change was partly prompted by the concern that the government's explicit involvement in international projects may be politically inconvenient. Unlike the central companies that owned tangible assets and specialized in certain business fields, the main function of the provincial windows was to mediate other companies' international businesses. Some local international companies were shell companies ("briefcase companies" in Chinese) that picked up overseas deals by using their contacts to pass on to others. Window companies were also encouraged to set up subsidiaries in provinces, thus enabling local, non-window companies to "sail to the ocean on others' boats" (jiechuan chuhai), as official documents at that time had it. In the beginning, the subcontractor companies sent their own employees overseas to carry out projects. But with the introduction of contractbased labour relations aimed at replacing life-long tenure, a reform initiated by the central government, they increasingly recruited contract workers through open hiring for the overseas projects. Thus at least two steps of mediation were involved: first, that of international business by "window" companies; second, that of labour by the subcontractors.

Although the state effectively crushed the intermediary class and monopolized the legitimate forms of international labour placement, this did not eradicate illegal migration, which increased significantly in the 1980s and the 
1990s. Illegal migration took place outside of state control and was brokered by multiple intermediaries, but this does not mean that it was completely unrelated to the state; it was partially a result of the emergence of the so-called "nongovernmental channels" of outmigration in southern China. The nongovernmental channel was an extension of the space of mediation controlled by the state. From the mid-1980s, increasing numbers of employers from Hong Kong and Taiwan travelled to Guangdong and Fujian to recruit workers through their personal networks for fishery and factory jobs in Southeast Asia and Saipan. ${ }^{7}$ Provincial government encouraged this and initially ordered local window companies to help with the workers' passports, visas and other paperwork for free, though most companies soon started charging window fees. Xiamen International, a major window company in Fujian province, sent out 40,000 workers between 1984 and 2004, the majority being nongovernmental, with about $85 \%$ hired by overseas Chinese in Southeast Asia and the south Pacific. ${ }^{8}$

Non-governmental channels led to large-scale undocumented migration. According to a retired cadre whom Xiang interviewed, a major state-owned company in Shanghai with the "window" status sent more than 3,000 people to Japan every year in late 1980s through the non-governmental channel. The company worked with informal brokers who recruited the would-be migrants who planned to immigrate to Japan, the company then arranged the paperwork for short-term visits or temporary jobs, knowing that most of the migrants would over-stay their visas. The fact that this channel was endorsed by stateowned companies on paper made this form of undocumented migration particularly rampant. Another type of undocumented migration was entirely brokered by informal networks. These individuals did not register companies, and therefore could not provide documents. Transnationally connected, they instead transported people into the destination physically, for instance by voyaging across the Pacific to North America, or by taking a bus or train across Eurasia into western Europe (Smith, 1997; Chin, 1999; Kyle and Liang, 2001; Chin, 2003). Although formally criminalized by the state, the critical part of the networks, namely the "snakeheads" (also known as "yellow ox" in some parts of China) in the migrant-sending communities, were often tacitly tolerated by the grassroots authorities. Apart from the deep roots of human smugglers in the community, local government also hoped that emigrants would contribute to the local economy through remittances (Chin, 2003; Xiang, 2003). In any case, it was no longer possible to develop an autonomous space of mediation free from state intervention as in pre-modern times. A telling example is the role of returned migrants. While returnees were among the most active brokers in the pre-modern times because of their transnational networks, they played a minimum role in the time of nation-states. This is because returnees, often uneducated and unconnected to the state, simply did not have the necessary resources to act as brokers in the new context.

\footnotetext{
7 Beijing allowed Taiwan fishing boats to anchor at designated ports in Fujian; owners of the boat often recruited labor on shore nearby. Hong Kong and Taiwan garment factories relocated to South Pacific countries and Guam and Saipan of the U.S, in the 1980s and 1990 s in order to avoid tariff imposed by the international textile quota system.

8 Interview with deputy director general, Xiamen International, February 25, 2005, Xiamen.
} 
The existence of undocumented migration, in both Indonesia and China, should not be regarded as a sign of state failure in controlling the space of mediation. The very fact that undocumented migration is categorized in this way, or as "irregular" or "illegal", is a product of the state's attempt in monopolizing the "legitimate means of movement" (Torpey, 2000: 5). In fact, it is not possible to conceptualize "illegal" without reference to "legal" migration. Human smugglers had simply remained capable community members if the state had not attempted to undermine their social and cultural authority or even criminalize them. Furthermore, as in Indonesia, it is clear that illegal migration in fact was a significant source of income for state officials, thus illustrating how illegal channels were related to the state-controlled space of mediation in operation. In China, the government launched a series of campaigns against human smuggling in the 1990s primarily because the central state regarded undocumented outmigration as a sign of the disobedience of local government (Xiang, 2003). The crackdown, however, was more a contestation between the central and local governments, rather than a battle between legal and illegal spheres. These efforts brought about a new configuration of the space of mediation at the turn of the millennium, which we will turn to now.

\section{The Professionalization of the Space of Mediation}

The space of mediation of labour outmigration from Indonesia and China has expanded significantly since the late 1990s. The volume of migration has increased rapidly, there has been a liberalization of regulation over individual outmigration, and, most importantly, there has been a dramatic growth of migration brokerage. At the same time both the Indonesian and Chinese states have attempted to shape and control the space of mediation through unprecedentedly hands-on regulations. Indonesia has attempted to formalize the relationship between informal labour recruiters and licensed companies through biometric technology and a broader database system, while China has tried to develop a system in which, in the words of an official in Liaoning province, "agents, officials and migrants all have laws to rely on and rules to follow at every step." ${ }^{\prime 9}$ As detailed below, both countries went through simultaneous de-regulation and re-regulation. De-regulation were policy changes that encouraged outmigration and allowed for more private players to become legitimate migration intermediaries. But at the same time both states set stricter rules for licensing and guidelines for the intermediary business, thus a process of re-regulation. The simultaneous process of de-regulation and re-regulation turned the space of mediation into a professional domain open to anyone who was qualified and was thus no longer monopolized by public institutions. But as a professional domain, only those who satisfy the state requirement regarding their professional capacity can become recognized players.

Indonesia witnessed significant transformations during the period after the Asian economic crisis and the fall of Suharto in 1998. While the New Order was "characterized by a powerful military, centralized decision-making, violent repression, and ideological control," the current era can be framed most broadly in terms of "democratization" and "decentralization" (Van Klinken and Barker,

9 Interview, June 2, 2006, Shenyang, Liaoning province. 
2009: 2); the military has lost much of its power and prestige, there has been a dramatic growth of political parties, NGOs, and other civil society groups, and political decentralization has given provinces and districts, and thereby local actors, greater autonomy. Aspinall (2013) describes Indonesia as a "nation in fragments" that should be conceptualized in relation to two sources, namely patronage and neoliberalism. More specifically, contemporary Indonesia is characterized by decentred clientelism in the context of state decentralization, in contrast to the heavily centralized clientelism of Suharto's New Order, which has "shifted power relations within patron-client relationships" and have tipped "the balance more in favour of the clients" (Ibid.: 31, emphasis in original). This decentred clientelism is particularly evident in the context of international migration, as the number of licensed recruitment agencies have increased dramatically with the liberalization of licensing and the increasing demand for documented migration following the collapse of the Indonesian rupiah. More specifically, this decentring is reflected in the increasing power of the petugas lapangan who are the actual recruiters in villages across the Indonesia, and who have increasingly come to control migrants and thereby profits. The space of mediation has thus come to flourish after 1998.

The Asian financial crisis was a watershed for international migration, as the collapse of the Indonesian rupiah and highly publicized mass deportations of undocumented workers from Malaysia led migrants to turn to documented channels. ${ }^{10}$ The collapse of the Indonesian rupiah and an intensifying Malaysian deportation regime aimed at undocumented migrants led to the rapid increase in the number of documented migrants, which quadrupled to nearly 800,000 annually within a decade; the majority female domestic care workers and male construction or oil palm workers. Recurring abuses against domestic workers abroad, and the widely acknowledged extortion of returning migrants - all in the context of an increasingly vibrant civil society - led to an intensifying focus on the "protection" (perlindungan) of migrants. ${ }^{11}$ At the same time there has been a dramatic decline in transmigration, not least in the context of political decentralization, through which it has been viewed as marginalizing local populations and only benefiting migrants rather than sending communities (Tirtosudarmo, 2009: 11). In contrast, as in other parts of the world, the remittance economy has become the new site for grassroots development, and the migrant has been transformed from a site for social engineering into an entrepreneur.

In tandem with political decentralization, there have been attempts to centralize the regulation of international migration. In 2006, the National Agency for the Placement and Protection of Indonesian Migrant Workers (Badan Nasional Penempatan dan Perlindungan Tenaga Kerja Indonesia, BNP2TKI) was created to coordinate government activities, both on the national and provincial levels. Licensed recruitment companies are increasingly regulated by the government. Each recruitment company must pay a 50,000 US dollar cash bond for licensing

10 See Hugo (2012: 399) for the increase in documented migration. There is no data on the drop in undocumented migration, but on-going fieldwork in migrant-sending areas, in tandem with Malaysian deportation programs point to a significant drop (e.g. Lindquist, 2010).

11 For instance, a specified migrant reception terminal at Jakarta international airport opened in August 1999 (Silvey, 2007). 
and is bound to specific procedures - for instance, a strict process of documentation and compulsory pre-departure training - which increasingly has come to integrate commercial and regulatory infrastructures, not least on the provincial level where most recruitment takes place. There are also regulations concerning the signing of contracts between recruitment companies and employers abroad, which must be mediated by Indonesian government representatives. While the head offices sign the job orders, it is the provincial branch offices that organize the actual recruitment process.

As of 2013 there were 546 licensed recruitment companies (compared to less than fifty in the middle of the 1990s) with approximately 4,000 branch offices around the country ${ }^{12}$, as well as an inestimable number of petugas lapangan, though these numbers have dropped with the ongoing moratorium on sending migrant workers to the Middle East (Platt, 2018). The petugas lapangan who recruits and delivers migrants to licensed agencies has in an important sense replaced the migrant smuggler, or tai kong, of the earlier era, but is also reminiscent of the laukeh from the colonial era. Although in some cases former tai kong have become petugas lapangan, the primary difference between the two is that while tai kong escorted undocumented migrants across great distances, petugas lapangan work within a more constricted space, delivering migrants to local recruitment companies while dealing with government paperwork. While the term suggests formality, in fact the petugas lapangan works without contracts and includes a wide range of actors, including low-level civil servants and return migrants. Of critical importance is that they are able to negotiate the interface between village environments, government offices, and recruitment companies (Lindquist, 2012; see also Spaan and Hillman, 2013).

In order for a villager to become a migrant there is an extensive process of documentation. The language associated with documents - tembak, to shoot, or jalan tol, toll road, for instance - points to the extra costs involved in accessing documents quickly. The road metaphor is apt since the process of documentation entails that the petugas lapangan escorts prospective migrants to government offices and spends time waiting for documents to be produced. Great distances, bad roads, and lack of public transportation make mobility arduous and expensive in many areas. Despite the ubiquity of cell phones and that most documented migrants now travel directly by airplane rather than overland, it is the movement of migrants to the urban-based recruitment company prior to departure that is the main logistical problem. It is thus in the space between rural and urban areas different brokers temporarily collaborate. In this process, petugas lapangan particularly those who are most successful and considered reliable by recruitment companies - are able to control capital, documents, and the migrants themselves, generally without having direct access to foreign markets. Much of this power is based on relations of trust with prospective migrants. In this process, what a figure who was initially imagined as being an extension of the state apparatus, or in the case of international migration, the licensed recruitment company, has in practice come to function as a broker between different societal spheres.

12 Lindquist interview with office manager at the head office of APJATI, the Indonesian Manpower Services Association (Asosiasi Jasa Tenaga Kerja Indonesia), in Jakarta, June 4, 2014. Of the 546 licensed companies, 461 were members of APJATI, and these had a total of 3,227 licensed branch offices. 
The petugas lapangan has therefore been at the centre of regulatory reform. Beginning in 2012, BNP2TKI in collaboration with APJATI (Asosiasi Jasa Tenaga Kerja Indonesia), the Indonesian Manpower Services Association, the national organization for licensed recruitment companies, initiated a government-controlled licensing system for petugas lapangan, who were to be registered in a database using biometric technology, representing in effect a radical attempt to formalize or professionalize the informal and control the space of mediation. This was ideally supposed to allow recruitment companies and government agencies to regain control over the recruitment process and profits. More generally, this was part of BNP2TKI's broader attempt to create a migrant labour database based on biometric technology in an ongoing shift to e-governance (Lindquist, 2018). Although some dimensions of these reforms have failed - not least because of intra-governmental conflicts (Palmer, 2016) - in the space of mediation that has taken shape through the expansion of labour recruitment, it is possible to see an ongoing process of re-regulation that aims to control and professionalize recruiters on a number of different levels.

In China, the expansion of the space of mediation was driven by liberalization on two fronts, individual outmigration and migration brokerage. The policy consensus in the 1990s was that migration must be made freer. First, nearly twenty administrative procedures in the passport application were cut out, and by 2005 most urban residents were able to apply for a passport by presenting their identity cards. The Passport Law, effective from January 2007, enshrined every citizen's legal entitlement to possess a passport. As a result, the annual outflow of labour migrants increased from 253,000 in 2000 (China International Contractors' Association, 2004: 10) to 530,000 in 2015 (China International Contractors' Association, 2016: 5.). Second, in 2002 there was a watershed policy change regarding labour recruitment companies, which were allowed into the business while at the same time public and government institutions were banned from the business in order to maintain the integrity of both the market and state. The number of licensed companies increased from four in 1979, all state-owned (Zhang Gesheng, 1999: 206), to about 3,000 in 2010, though the number dropped to about 1,000 afterwards. ${ }^{13}$

The Chinese government thus consciously attempted to govern migration through commercial intermediaries. But this obviously presented challenges. Unlike the pre-reform era when licensed companies were state-owned and obliged to follow government orders, the newly licensed companies are independent enterprises. Furthermore, while the government could previously stop companies from sending workers at a moment's notice by withholding project approvals or workers' passports, the liberalization of exit control meant this was no longer feasible. In this context, the government regarded clear, pre-set and impartial rules, rather than via ad hoc, direct and arbitrary interventions, as the way forward. Licensing is the central practical leverage through which the state regulates the migration brokerage. All companies must meet sets of strict criteria

13 The 3,000 recruitment companies included those licensed by the ministries of commerce, labor, transport (specializing in sea farers) and health (specializing in nurse migration). Companies licensed by the ministries of education and public security (for permanent emigration and general-purpose border crossing) sometimes engaged in labor migration as well (estimate based on CHINCA, 2004-2012; Center for International Exchanges, Ministry of Labour and Social Security, 2008; Xia Hong, 2012:52). 
to be licensed. They are subject to annual reviews, and those who fail to provide satisfactory documentary evidence about their business performance are delicensed. Regulators placed great emphasis on companies' capacity. They identified companies' financial capacity as the foundation for business success and the determinant of their credibility. "What is credibility?" the official in Liaoning province asked, "If you have the [financial] capacity to pay the full compensation [in case of failure in service], you have the credibility. If you can't compensate, what credibility can you talk about?" The labour ministry set the national policy in 2002 that all agents had to pay a minimum financial bond of USD 60,000 when applying for licenses, a figure that has increased nearly ten-fold since. ${ }^{14}$

Apart from the stress on financial capacity, the Ministry of Labour urged all agents to develop the "capacity of resisting risks." All companies were required to submit a report on their "emergency coping mechanisms" when applying for licenses from 2005 onwards. The report details the procedure, the division of labour, the staff and the telephone numbers designated, and the budget earmarked for dealing with emergencies such as when workers stage strikes overseas. A much more difficult requirement in the license application is that agents must have appointed their legal representatives in destination countries. In addition, it is compulsory that intermediary companies have staff with work experience in international relations and career development. The government also stressed strict documentation procedure. For instance, licensed intermediary companies were required to submit their Service Agreements (between agents and migrants), Employment Contracts (between foreign employers and migrants), proof of the overseas employer's legal status and the foreign government's permissions for hiring migrant workers. The companies also have to declare that they have checked all the details in the contracts against laws and regulations of the local government, the national government, and in the destination country. Obviously only a small number of intermediaries could meet these requirements. The scientific regulation was inevitably exclusive. It reinforced the monopoly position of the windows. This unintentionally complicated the space of mediation. What emerged was a multi-layered system of "intermediary chains." At the top of the chain are window companies in major cities. They sign contracts with foreign firms and process the legal paperwork that was necessary for outmigration, but outsourced the task of labour recruitment to middle-level agents in the prefectures, who in turn subcontract to subagents in local districts or rural townships, who are referred to colloquially as "the legs," akin to the Indonesian petugas lapangan. When the overseas employer complains to the recruitment agent in the destination country about a migrant, the foreign agent pressures the window company to seek quick solutions, and the "window" often passes the task downward to the "leg," who disciplines the migrant transnationally by pressuring the migrant's family in the home country.

14 Liaoning province, for example, doubled the minimum bond from the national level of USD 60,000 in 2002 to USD 120,000 in 2007. The national level was then raised to USD 500,000 in 2012 (State Council, 2012). Ministry of Labor. 2002 [Decree No. 7]. Provincial Rules on Security Bond for International Labor Cooperation. In Liaoning, the agent must deposit the bond with a designated bank. The bank, the agent and the provincial labor bureau sign a three-party legal contract that forbids the bank and the agent from withdrawing the money without the government's permission, but authorizes the government to use the money to deal with emergencies caused by the agent, particularly to compensate for migrants' losses. 
The space of mediation is still evolving. In 2010, the State Council designated the Ministry of Commerce as the single authority to oversee land-based labour outmigration. The Ministry of Commerce cut down the number of licensed companies significantly, partly aimed at driving those connected to other ministries, especially the Ministry of Labour, out of the business. At the same time the Ministry of Commerce launched a campaign to set up "labour service platforms" at the county level, and by the end of 2015, there were 310 such platforms across the country (CHICA, 2016: 14). The platforms are networks of government departments coordinated by a specially created government agency, which have direct access to the labour force and to window companies, and are thus able to process the entire recruitment procedure. In other words, it aims to create a new regulatory infrastructure to "flatten" the multi-layered commercial infrastructure. It remains to be seen how this will affect the intermediary business and labour outmigration in general.

Simultaneous deregulation and re-regulation as demonstrated in both Indonesia and China represents a common policy trajectory among a number of Asian countries. In the era of globalization, developmental states deregulate the economy in order to join the global market, but at the same time reintroduce regulations in order to safeguard their economic sovereignty or capture profits. In Indonesia and China, labour migration mediation is deregulated by opening space for private actors and adopting market mechanisms. This is aimed at promoting outmigration for developmental goals. At the same time the business is reregulated in order to protect migrants' rights and to reinforce government's executive power. Licensing turns out to be the chief method of achieving simultaneous de-regulation and re-regulation. Those who are licensed are supposed to be professionally qualified and will therefore mediate labour outmigration in ethical and efficient ways. Although unlicensed entities are still an important part of the scene, they work as subagents of licensed companies and are closely monitored. In sum, the space of mediation has both privatized and professionalized.

\section{Conclusion}

Migration should not be understood as constituting migrants' activities per se. Migrations in modern times are to a great extent constituted by multiple actors other than migrants. These actors are interconnected and thus create a "space of mediation". Based on historical comparison between Indonesia and China, this article shows that the composition and dynamic of such space has changed over time, which is an integral part of the changing political order in general. Before the mid-twentieth century, the space of mediation arose in response to the emerging modern statecraft that was alien to the local society. The space of mediation linked the process of migration to the administrative regulation imposed from above and afar. At the same time the space of mediation was sufficiently distanced from the power that it could become a site of resistance and even revolutionary activities. The space of mediation shrank dramatically after Indonesia and China became full sovereign nation-states that administered migration processes directly. After the 1990s, outmigration was encouraged, exit control liberalized, and migration increased significantly. The most important consequence of liberalization, however, has been the growth and complication 
of the intermediary business. As we have documented elsewhere, the migration intermediary industry increased much faster than migration itself in both China and Indonesia (Xiang and Lindquist, 2014). The space of mediation has once again assumed a central role in low-skilled labour migration.

The space of mediation and the state are not in opposition. The space of mediation did not necessarily contract when the state expanded, nor did it necessarily "bounce back" when the state retreated. As our historical comparison shows, it was the collapse of the traditional order and the efforts of modern state building that gave rise to the space of mediation in the late nineteenth and early twentieth century. Similarly, the growth of the space of mediation since the 1990s is accompanied by increasingly sophisticated regulation in both countries. As such, it is more productive to investigate how state and non-state actors overlap, rather than how they are separated. This allows us also to distinguish our work from the work of scholars such as Peck and Tickel (2002), who conceptualize the "roll-back" and "roll-out" of the state strictly in relation to recent processes of neoliberalization. As Huang has put it in his research on Chinese history, "contrary to the vision of the public sphere/civil society models, actual socio-political change in China has really never come from any lasting assertion of societal autonomy against the state, but rather from the workings out of state-society relations in the third realm" (Huang, 1993: 238). By the "third realm" Huang means a space that is distinct from state and society but which both participate in. Examples include the imperial justice system in which the state endorsed community arbitrations, which was how the majority civil cases were settled, and the rural gentry class under the county level who represented both state interests and local concerns. The space of mediation can be seen as part of the third realm.

By construing the space of migration mediation as a site where bureaucratic operations and social activities co-evolve, our comparison also sheds light on the question of whether the current era of globalization is a continuation or even repetition of the developments of the nineteenth century. History has not simply gone through a cycle. The contemporary space of mediation differs from the link society in multiple ways. The space of mediation after the 1990s is to a great extent based on the social infrastructure built by the state. The petugas lapangan was cultivated by the Indonesian state during the New Order, and in China the space of mediation was developed primarily through the corporatization of government agencies. Most privately-owned intermediaries were once state-owned, and their unlicensed sub-agents were often government agencies or public institutions (such as vocational schools). The "legs" were usually persons who enjoyed public authority such as retired cadres or school teachers. The connections with the state ran deep and wide. As such, the era of national development was decisive in shaping on-going transnational flows and connections. The increase of labour migration after the 1990s is more an expansion of national development projects than a "return" to the pre-nation state models.

Will the contemporary space of mediation become more autonomous in time? For instance, will rights-focused NGOs in Indonesia play a countervailing role against commercial intermediaries? Will the new "labour service platforms" in China become a basis for reorganizing public life at the grassroots level? Or will NGOs, now extremely weak in China, one day emerge to put state power 
in check? These questions can only be addressed by further empirical research. They are clearly not unique to labour outmigration, and are related to such issues as the roles of political parties and local-central relations. As such, the notion of space of mediation may provide a tool for investigating more general social transformations that take place on multiple fronts but often appear contradictory, as we are witnessing in many Asian countries today.

\section{References}

Abdullah Taufik (1978) The Making of a Schakel Society: The Minangkabau Region in the Late Nineteenth Century, Papers of the Indonesian-Dutch History Conference, Noordwijkerhout, The Netherlands, 19-22 May 1976, Leiden/Jakarta, Bureau of Indonesian Studies, pp. 143-153.

Amrith Sunil (2011) Migration and Diaspora in Modern Asia, Cambridge, Cambridge University Press, 240 p.

Anderson Benedict (1983) Old State, New Society: Indonesia's New Order in Comparative Historical Perspective, Journal of Asian Studies, 42 (3), pp. 477-496.

Aspinall Edward (2013) A Nation in Fragments: Patronage and Neoliberalism in Contemporary Indonesia, Critical Asian Studies, 45 (1), pp. 27-54.

Bailey Paul (2014) Chinese Labour in World War I France and the Fluctuations of Historical Memory, Studies in Ethnicity and Nationalism, 14 (2), pp. 362-382.

Barker Joshua (1999) The Tattoo and the Fingerprint: Crime and Security in an Indonesian City, PhD dissertation, Cornell University, 342 p.

Barker Joshua and Van Klinken Gerry (2009) Reflections on the State in Indonesia, in Gerry Van Klinken and Joshua Barker Eds., State of Authority: The State in Society in Indonesia, Ithaca, NY, Cornell Southeast Asia Program, pp. 19-46.

Breman Jan (1990) Labour Migration and Rural Transformation in Colonial Asia, Amsterdam, Free University Press, $82 \mathrm{p}$.

Breman Jan (1988) The Shattered Image: Construction and Deconstruction of the Village in Colonial Asia, Dordrecht, Holland, Foris Publications, 49 p.

Cao Shuji (1997) China's Migration History: Qing and Republic of China, volume VI, Fuzhou, Fujian People's Publishing House,.

Chin James (2003) Reducing Irregular Migration from China, International Migration, 41 (3), pp. 49-72.

Chin Ko-lin (1999) Smuggled Chinese: Clandestine Migration to the United States, Philadelphia, Temple University Press, 221 p.

China International Contractors' Association (2016) Zhongguo Duiwai Laowu Hezuo Niandu Baogao 2016 [Annual Report on China's International Labour Collabouration], Beijing, International Contractors' Association.

China International Contractors' Association (2004) Zhongguo Duiwai Laowu Hezuo Niandu Baogao 2004 [Annual Report on China's International Labour Collabouration], Beijing, International Contractors' Association. 
Cremer Georg (1988) Deployment of Indonesian Migrants in the Middle East: Present Situation and Prospects, Bulletin of Indonesian Economic Studies, 24 (3), pp. 73-86.

Cribb Robert (1993) Development Policy in the Early 20th Century [Indonesia], in Jan-Paul Dirkse, Frans Hüsken and Mario Rutten Eds., Development and Social Welfare: Indonesia's Experiences Under the New Order, Leiden, KITLV Press, pp. 225-245.

Dirlik Arif (1991) Anarchism in the Chinese Revolution, Berkeley, University of California Press, 336 p.

Duara Prasenjit (1987) State Involution: A Study of Local Finances in North China, 1911-1935, Comparative Studies in Society and History, 29 (1), pp. 132-161.

Feldman Gregory (2012) The Migration Apparatus, Palo Alto, Stanford University Press, 224 p.

Guo Liang (1989) Huaqiao Chuguoshi Liushu (A Brief Account of the Emigration History of Overseas Chinese), in Zheng Min and Liang Chu Eds., Huaqiao Huaren Shi Yanjiu Ji (Collections of the Studies on the History of Overseas Chinese), volume 1, Beijing, Haiyang Publishing House, pp. 118-137.

Hardjono Joan (1988) The Indonesian Transmigration Program in Historical Perspective, International Migration Review, 26 (4), pp. 427-439.

He Xiankai (Ed.) (1994) Practice of International Labour Cooperation (Guoji Laowu Hezuo Shiwu), Beijing, Beijing Industrial University Press.

Hoefte Rosemarijn and Meel Peter (2018) Departing from Java, in Rosemarijn Hoefte and Peter Meel Eds., Departing from Java: Javanese Labour, Migration and Diaspora, Copenhagen, NIAS Press, $288 \mathrm{p}$.

Houben Vincent (2018) Colonial Capitalism and Javanese Transcolonial Labour Migration in Insular Asia, in Mahua Sarkar Ed., Work Out of Place, Berlin, Oldenbourg De Gruyter, pp. 55-76.

Houben Vincent (1999a) Introduction:The Coolie System in Colonial Indonesia, in Vincent Houben and Thomas Lindblad Eds., Coolie Labour in Colonial Indonesia: A Study of Labour Relations in the Outer Islands of Indonesia, c. 1900-1940, Wiesbaden, Harrassowitz, pp. 25-42.

Houben Vincent (1999b) Before Departure: Coolie Labour Recruitment in Java, 1900-1942, in Vincent Houben and Thomas Lindblad Eds., Coolie Labour in Colonial Indonesi:. A Study of Labour Relations in the Outer Islands of Indonesia, c. 1900-1940, Wiesbaden, Harrassowitz, pp. 25-42.

Huang Philip (1993) "Public Sphere"/“Civil Society" in China?: The Third Realm Between State and Society, Modern China, 19 (2), pp. 216-240.

Hugo Graeme (2012) International Labour Migration and Migration Policies in Southeast Asia, Asian Journal of Social Science, 40, pp. 392-418.

Jones Sidney (2000) Making Money off Migrants. The Indonesian Exodus to Malaysia, Hong Kong, Asia Ltd., 157 p.

Kaur Amarjit (2004) Labour Dynamics in the Plantation and Mining Sectors in Southeast Asia, 1840-1950: A Historical Perspective, in Rebecca Elmhirst and Ratna Saptari Eds., Labour in Southeast Asia: Local Processes in a Globalised World, London, Routledge Curzon, pp. 47-76. 
King Dwight (1982) Indonesia's New Order as a Bureaucratic Polity, a Neopatrimonial Regime or a Bureaucratic Authoritarian Regime: What Difference Does It Make?, in Benedict Anderson and Audrey Kahin Eds., Interpreting Indonesian Politics: Thirteen Contributions to the Debate, Ithaca, Cornell University Press, pp. 104-116.

Kuhn Philip (2008) Chinese among Others: Emigration in Modern Times, Lanham, Rowman \& Littlefield Publishers, 452 p.

Kuhn Philip (2002) Origins of the Modern Chinese State, Palo Alto, Stanford University Press, $176 \mathrm{p}$.

Kuitenbrouwer Maarten (1980) The Concept of Middleman and the Study of Indonesian History, in Gerrit Schutte and Heather Sutherland Eds., Papers of the Dutch-Indonesian Historical Conference, Leiden, Bureau of Indonesian Studies, pp. 98-128.

Kyle David and Liang Zai (2001) Migration Merchants: Human Smuggling from Ecuador and China, UC San Diego: Center for Comparative Immigration Studies, [online] last checked on 19/07/2018. URL: https://escholarship.org/uc/ item/5h24b7j6

Li Minghuan (2002) Ouzhou Huaqiao Huaren Shi (A History of Chinese Immigrants in Europe), Beijing, Zhongguo Huaqiao Chuban Sh.

Lindquist Johan (2018) Reassembling Indonesian Migration: BiometricTechnology and the Licensing of Informal Labour Brokers, Ethnos, 83 (5), pp. 832-849.

Lindquist Johan (2015) Brokers and Brokerage, Anthropology of, in James D. Wright Ed., International Encyclopedia of the Social \& Behavioral Sciences, Volume 2, Oxford, Elsevier, pp. 870-874.

Lindquist Johan (2012) The Elementary School Teacher, the Thug and his Grandmother: Informal Brokers and Transnational Migration from Indonesia, Pacific Affairs, 85 (1), pp. 69-89.

Lindquist Johan (2010) Labour Recruitment, Circuits of Capital and Gendered Mobility: Reconceptualizing the Indonesian Migration Industry, Pacific Affairs, $83(1)$, pp. 115-132.

Lindquist Johan, Biao Xiang and Yeoh Brenda (2012) Opening the Black Box of Migration: Brokers, the Organisation of Transnational Mobility, and the Changing Political Economy in Asia, Pacific Affairs, 85 (1), pp. 7-20.

Ma Li (2015) Yizhan Huagong Zai Faguo (Chinese Workers in First World War France), Changchun, Jilin Publishing Group Limited.

Mao Qunzhong (2004) Xielei Banban De Guangxi Zaoqi Laowu Shuchu [Blood and Tears in the Early Period of Labour Export from Guangxi], Wenshi Chunqiu [Annals of Culture and History], 1, pp. 4-5.

McKeown Adam (2008) Melancholy Migration: Asian Migration and the Globalization of Borders, New York, Columbia University Press, 472 p.

Mezzadra Sandro and Neilson Brett (2013) Border as Method, or, the Multoplication of Labour, Durham, Duke University Press, 384 p.

Mrázek Rudolf (2002) Engineers of Happy Land:Technology and Nationalism in a Colony, Princeton, NJ, Princeton University Press, 336 p.

Niehof Anke and Lubis Firman (Eds.) (2003) Two is Enough: Family Planning in Indonesia Under the New Order 1968-1998, Leiden, KITLV Press, 281 p. 
O’Neill Mark (2014) The Chinese Labour Corps: The Forgotten Chinese Labourers of the First World War, Sydney, Penguin Random House Australia, 122 p.

Ong Jin Hui (1995) Chinese Indentured Labour: Coolies and Colonies, in Robin Cohen Ed., The Cambridge Survey of World Migration, Cambridge, Cambridge University Press, pp. 51-56.

Palmer Wayne (2016) Indonesia's Overseas Labour Migration Programme, 19692010, Leiden, KITLV Press, 202 p.

Peck Jamie and Tickell Adam (2002) Neoliberalizing Space, Antipode, 34 (3), pp. 380-404.

Platt Maria (2018) Migration, Moralities and Moratoriums: Female Labour Migrants and the Tensions of Protectionism in Indonesia, Asian Studies Review, 42 (1), pp. 89-106.

Rush James (1990) Opium to Java: Revenue Farming and Chinese Enterprise in Colonial Indonesia, 1860-1910, Ithaca, Cornell University Press, 281 p.

Silvey Rachel (2007) Unequal Borders: Indonesian Transnational Migrants at Immigration Control, Geopolitics, 12 (2), pp. 265-279.

Smith Paul J. (Ed.) (1997) Human Smuggling, Chinese Migrant Trafficking and the Challenge to America's Immigration Tradition, Washington DC, The Center for Strategic \& International Studies, 224 p.

Sørensen Ninna Nyberg and Gammeltoft-Hansen Thomas (2013) Introduction, in Ninna Nyberg Sørensen and Thomas Gammeltoft-Hansen Eds., The Migration Industry and the Commercialization of International Migration, London, Routledge, pp. 1-23.

Spaan Ernst (1999) Labour Circulation and Socioeconomic Transformation. The Case of East Java, Indonesia, The Hague, Netherlands Interdisciplinary Demographic Institute (NIDI), $374 \mathrm{p}$.

Spaan Ernst (1994) Taikongs and Calos: The Role of Middlemen and Brokers in Javanese International Migration, International Migration Review, 28 (1), pp. 93-113.

Spaan Ernst and Hillman Felcitas (2013) Migration Trajectories and the Migration Industry: Theoretical Reflections and Empirical Examples from Asia, in Ninna Nyberg Sørensen andThomas Gammeltoft-Hansen, Eds., The Migration Industry and the Commercialization of International Migration, London, Routledge, pp. 64-86.

Stoler Ann (1985) Capitalism and Confrontation in Sumatra's Plantation Belt, 1870-1979, New Haven, Yale University Press, 296 p.

Sutherland Heather (1979) The Making of a Bureaucratic Elite: The Colonial Transformation of the Javanese Priyayi, Singapore, Heinemann Educational Books, $182 \mathrm{p}$.

Termorshuizen Thio (2008) Indentured Labour in the Dutch Colonial Empire 18001940, in Gert Oostindie Ed., Dutch Colonialism, Migration and Cultural Heritage: Past and Present, Leiden, Brill, pp. 261-314.

Tirtisudarmo Riwanto (2009) Mobility and Human Development in Indonesia, MPRA Paper No. 19201, [online] last checked on 10/03/2014. URL: http://mpra. ub.uni-muenchen.de/19201/ 
Tirtosudarmo Riwanto (2001) Demography and Security: Transmigration Policy in Indonesia, in Myron Weiner and Sharon Russell Eds., Demography and National Security, London, Berghahn, pp. 199-211.

Torpey John (2000) The Invention of the Passport: Surveillance, Citizenship and the State. Cambridge, Cambridge University Press, 224 p.

Walters William (2015) Migration, Vehicles, and Politics: Three Theses on Viapolitics, European Journal of Social Theory, 18 (4), pp. 1-20.

Warwick Donald (1986) The Indonesian Family Planning Program: Government Influence and Client Choice, Population and Development Review, 12 (3), pp. $453-490$.

Wilson, Ian (2015) The Politics of Protection Rackets in Post-New Order Indonesia: Coercive Capital, Authority and Street Politics, London, Routledge, 220 p.

Wood Frances and Arnander Christopher (2016) Betrayed Ally: China in the Great War, Barnsley: Pen \& Sword, 224 p.

Wu Han and Fei Xiangtong (Eds.) (1948) Huangquan Yu sShenquan (Emperor and Gentry), Shanghai, Guanzha Press.

Xiang Biao (2003) Emigration from China: A Sending Country's Perspective, International Migration, 41 (3), pp. 21-48.

Xiang Biao and Lindquist Johan (2014) Migration Infrastructure, International Migration Review, 48 (S1), pp. 122-148.

Xu Guoqi (2011) Strangers on the Western Front: Chinese Workers in the Great War, Cambridge, Harvard University Press, 366 p.

Zhang Gesheng (1999) Guoji Laowu Jingji [International Labour Economy], Chongqing, Chongqing Daxue Chubenshe [Chongqing University Press].

Zhang Jianguo (Ed.) (2009) Zhongguo Laogong Yu Diyici Shijie Dazhan (Chinese Labourers and the First World War), Jinan, Shandong University Press.

Zhuang Guotu (1994) Haiwai Maoyi He Nanyang Kaifa Yu Mingnan Huaqiao Chuguo De Guanxi (The Connection between the Overseas Trade and Southeast Asian Development to the Emigration of Overseas Chinese), Huaqiao Huaren Lishi Yanjiu (Research on the History of Overseas Chinese), 2, pp. 55-59. 


\section{Johan Lindquist and Biao Xiang}

\section{Space of Mediation: Labour Migration, Intermediaries and the State in Indonesia and China since the Nineteenth Century}

It is increasingly recognized that a focus on how migration is mediated by nonmigrants can provide a critical lens for examining the relationship between migration and broader social change. This article develops this approach further by examining the mediation process historically and comparatively. We compare the evolution of the complex relations among multiple actors that shape mobilities through what we call the "space of mediation", using the case of low-skilled international labour outmigration from Indonesia and China since the nineteenth century. In both countries, the space of mediation before the mid-twentieth century was large, quasi-autonomous, and poorly regulated. The space was brought under the control of centralized state in the second half of the twentieth century, and then bifurcated into state-managed labour exports and undocumented outmigration. On entering the twenty-first century, the space of mediation has become both privatized and professionalized, and more expansive, integrated and regulated.

\section{L'espace de la médiation : intermédiaires et État en Indonésie et en Chine depuis le XIXe siècle}

II est de plus en plus reconnu que la manière dont la migration est médiatisée par les non-migrants fournit une perspective critique pour examiner la relation entre la migration et le changement social plus large. Cet article examine le processus de médiation d'un point de vue historique et comparatif. Il compare l'évolution des relations complexes entre les multiples acteurs qui façonnent les mobilités à travers ce que nous appelons "l'espace de la médiation", dans le cas de l'émigration internationale de main-d'œuvre peu qualifiée d'Indonésie et de Chine depuis le XIXe siècle. Dans les deux pays, l'espace de la médiation avant le milieu du $\mathrm{XXe}$ siècle était vaste, quasi autonome et mal réglementé. L'espace a été placé sous le contrôle de l'État centralisé dans la seconde moitié du XXe siècle, puis a bifurqué vers des exportations de main-d'œuvre gérées par l'État et une émigration clandestine sans papiers. À l'aube du XXle siècle, l'espace de la médiation est devenu à la fois privatisé et professionnalisé, plus étendu, intégré et réglementé.

\section{Espacio de mediación: migración laboral, intermediarios y el Estado en Indonesia y China desde el siglo XIX}

Se reconoce cada vez más que un enfoque en la forma en que la migración es mediada por los no migrantes puede proporcionar una perspectiva crítica para examinar la relación entre la migración y el cambio social más amplio. Este artículo desarrolla este enfoque examinando el proceso de mediación histórica y comparativamente. Comparamos la evolución de las complejas relaciones entre múltiples actores que conforman las movilidades a través de lo que llamamos el "espacio de mediación», utilizando el caso de la emigración laboral internacional de baja cualificación desde Indonesia y China desde el siglo XIX. En ambos países, el espacio de mediación antes de mediados del siglo $\mathrm{XX}$ era amplio, casi autónomo y mal regulado. El espacio fue puesto bajo el control del estado centralizado en la segunda mitad del siglo $X X$, y luego bifurcado en exportaciones de mano de obra manejadas por el estado y emigración indocumentada. Al entrar en el siglo XXI, el espacio de la mediación se ha privatizado y profesionalizado, y se ha vuelto más amplio, integrado y regulado. 